Valóságos könyvtár - könyvtári valóság. Könyvtár- és információtudományi tanulmányok 2020. Szerk. Kiszl Péter, Boda Gáborné Köntös Nelli.

Budapest, ELTE BTK Könyvtár- és Információtudományi Intézet. 2021. 207-217.

\title{
GYULAFFI LESTÁR DIÁKÉVEI ${ }^{1}$
}

\section{BIBOR MÁTÉ JÁNOS}

ELTE BTK KITI Könyvtártudományi Tanszék, egyetemi tanársegéd

Asztalos István tanár úrnak

\section{TARTALMI ÖSSZEFOGLALÓ}

Gyulaffi Lestár (1556-1606. június 10. után) az Erdélyi Fejedelemség nagyobb kancelláriájának titkára volt, ma történeti följegyzések szerzőjeként ismert. Gyermekkorát a Dunántúlon töltötte, apja halála után egyik nagybátyja, a híres végvári vitéz, Gyulaffi László gondoskodott róla. Az ő segítségével került előbb Bécsbe, az alsó-ausztriai tartományi iskolába (Niederösterreichische Landschaftsschule), majd pedig az erdélyi fejedelmi udvarba. Az 1565-ben alapított, Bécsben múködő, császári fenntartású iskolával kapcsolatban fennmaradt iratok jelentős része a Gyulaffi Lestár által ott töltött évekre (1571-1574) vonatkozik. 1573-ból ismert a tanterv és egy ugyanebben az esztendőben lezajlott vizsgálat biztosainak jelentése is. Mindezekből viszonylag pontosan rekonstruálható, hogy hogyan teltek a tizenöt-tizennyolc éves Gyulaffi Lestár napjai.

Gyulaffi Lestár (Csobánc?, 1556. november 2. - Kolozsvár?, 1606. június 10. után) az Erdélyi Fejedelemség nagyobb kancelláriájának titkára volt, ${ }^{2}$ ma történeti följegyzések szerzőjeként ismert. ${ }^{3}$ Gyermekkorát a Dunántúlon (Csobáncban, Szigligeten, Kemenden és Körmenden) töltötte, apja halála (1559) után egyik nagybátyja, a híres végvári vitéz, Gyulaffi Lász̧ló (†Szamosudvarhely, 1579. május 13.) gondoskodott róla. Ő előbb a Magyar Királyságban volt tihanyi és veszprémi kapitány, ${ }^{4}$ majd - miután 1568-ban átpártolt II. János választott királyhoz, a későbbi (Szapolyai) János Zsigmond fejedelemhez - Erdélyben tanácsúr és a mezei hadak főkapitánya lett. ${ }^{5}$

Gyulaffi Lestámak sajnos nemcsak gyermek-, hanem ifjúkoráról is viszonylag kevés adat ismert. Egyelőre semmilyen konkrét információ nincs arról, hogy milyen - mai fogalommal élve - alapfokú oktatásban volt része. Arra, hogy valamilyen képzésben (legalább egy családi-udvari tanító akkoriban szokásos oktatásában) részesült, abból lehet következtetni, hogy később, Bécsben végzett középfokú tanulmányai során nagyon jól megállta a helyét. Mindenesetre a szúkebb és a tágabb családi háttér egyaránt megvolt ehhez, hiszen nemcsak édesanyja tudott írni, ${ }^{6}$ hanem például már említett nagybátyja is, ${ }^{7}$ pedig ő - bár támogatta Melius Juhász Péter egyik prédikációs kötetének kiadását ${ }^{8}$-, ahogy az a fentiekből is kitűnhet, mentes volt bármiféle értelmiségi beállítottságtól. 
BibOR MÁTÉ JÁNOS

Gyulaffi Lestár apai nagyapja, az általa is említett ${ }^{9}$ Gyulaffi István 1507-ben a Királyi Tábla bírája volt, őseinek többsége pedig (a XIII. századig visszamenően) magisterként szerepel. Ez az adott korban persze elsősorban presztízscím volt, de föltételezhetô, hogy Gyulaffi Lestár gyermekkorában már természetesnek számított, hogy a család tagjai valamilyen alapműveltségre tesznek szert. Ezt erősíti, hogy várukban, Csobáncban is voltak könyvek. ${ }^{10}$ Bár a Gyulaffi Lestárt követő nemzedék egyik tagja, Gyulaffi Mihály a XVI. század végén (Sáros)Patakon tanult, ${ }^{11}$ kifejezetten értelmiséginek nevezhető pályát a családból egyedül Gyulaffi Lestár futott be.

Egyelőre nem zárható ki, hogy 1568 őszén-telén Gyulaffi Lestár is nagybátyjával és annak családjával tartott, és velük együtt ment a Magyar Királyság Habsburg fennhatóság alatti részéből a Szapolyaiak uralmában lévő Erdélybe. Ez azonban igen valószínűtlen, két okból is. Egyrészt a szülei (ekkor már csak özvegy édesanyja) és Gyulaffi László közötti ellentétek miatt, másrészt pedig azért, mert fönnmaradt írásaiban maga Gyulaffi Lestár sem említi. Ír ugyan nagybátyja áttelepüléséről: ,Janos kirali fianak [= II. János választott királynak] hivataliara iw'tt volth be Erdelben", ${ }^{12}$ de egy szóval sem utal arra, hogy ő is jelen lett volna ennél az eseménynél. Márpedig fönnmaradt jegyzeteiben rendszerint jelzi, ha valaminek résztvevője vagy szemtanúja volt. Annak, hogy Gyulaffi Lestár Erdélyből került volna Bécsbe, szintén ellene szól az, hogy a tárgyalt időszakban ilyen irányú mozgás csak 1573-tól indult meg. ${ }^{13}$

Akár a Dunántúlon, akár Erdélyben és a Részekben (Partium) töltötte Gyulaffi Lestár az 1560-as évtized utolsó éveit, az biztos, hogy 1571. október 11-től a császári fenntartású alsó-ausztriai tartományi iskola (Niederösterreichische Landschaftsschule) diákja volt. ${ }^{14}$ Nagyon valószínű, hogy nagybátyja segítette bekerülni a nem sokkal korábban, 1565ben Bécsben megnyitott intézménybe. A szolgálatmegtagadás és a Szapolyaiakhoz való átpártolás miatt perbe fogástól tartó, harmadik éve Erdélyben, illetve a Partiumban élő Gyulaffi László ugyanis éppen 1571-ben békült ki Miksa német-római császár és magyar királlyal. Az uralkodó előbb kegyelemlevelet adott ki részére (1571. január 31.), ${ }^{15}$ majd pedig a vitéz legidősebb fiát, Gyulaffi Istvánt fölvette a bécsi udvari ifjak közé, mégpedig úgynevezett kétlovas szolgálóként. Ezt a tisztséget ő valószínúleg 1573. február 10-ig töltötte be, és ekkor távozott az udvartartásból. ${ }^{16}$ Gyulaffi István azonban később is megfordult az Udvarban: Rudolf király koronázási lakomájának (Pozsony, 1576. szeptember 25.) résztvevői között étekfogóként sorolták föl. ${ }^{17}$ Föltűnő, hogy Gyulaffi Lestámak az iskolába történő beiratkozását (1571. október 11.) és Gyulaffi István Bécsbe kerülésének időpontját (1571. november 6.) csak néhány hét választja el egymástól. Föltételezhető, hogy ez nem véletlen egybeesés, hanem mindkettő végső soron Miksa király és Gyulaffi László békülési gesztusainak része volt: a Bécsbe - tehát az uralkodói székhelyre - küldött, elsőszülött fiút Miksa király befogadta udvartartásába, az unokaöcsöt pedig fölvette az általa nemrég alapított iskolába. (A tanulók fölvételének jogát - az illetékes császári biztosok előterjesztése nyomán - az uralkodó magának tartotta fönn, és azt csak 1578-ban, már II. Rudolf császár engedte át az Udvari Kancelláriának. ${ }^{18}$ ) 
Az alsó-ausztriai tartományi iskolát és a hozzá tartozó kollégiumot - néhány, a század közepén létrejött példa nyomán - viszonylag szerény anyagi lehetőségű, saját nevelővel nem rendelkező nemesifjak részére alapította az uralkodó. (Nem nemeseket csak 1578-tól vettek föl.) Fontos volt az intézmény kifejezetten világi, főleg pedig nem kizárólagosan katolikus jellege, hiszen az alsó-ausztriai nemesség ekkoriban jellemzően - mai fogalmak szerint - evangélikus volt. Jelzés értékű, hogy az elsősorban az ő gyermekeik számára alapított tartományi iskolában a latin nyelvtan oktatása föként Melanchthon múveire, ${ }^{19}$ a görögé pedig nagyrészt a Johann Sturm-féle „strassburgi iskola” tananyagára ${ }^{20}$ épült, és a misén való részvétel elmulasztását sem vették túl szigorúan. Más kérdés, hogy hosszú távon az alsó-ausztriai nemesek még így sem találták semlegesnek - helyesebben szólva eléggé protestánsnak - az iskola beállítottságát, ezért az 1570-es évek végétől egyre kevesebben járatták oda gyermekeiket, olyannyira, hogy 1582-ben fölvetődött az intézmény bezárásának gondolata is. (Az iskola eredeti jellege végül csak 1623-ban szűnt meg, amikor az oktatást jezsuiták vették át.) ${ }^{21}$

1568 és 1594 között az intézménynek legalább 42 magyar diákja volt, közülük - a beiratkozás időrendjét tekintve - a király által a pártfogó nagybáty Gyulaffi Lászlóval együtt, 1563-ban aranysarkantyús lovaggá ütött ${ }^{22}$ Thury György fia volt az első, Gyulaffi Lestár pedig a második. (Minthogy Thury Pál 1570 nyarán távozott az iskolából, nem voltak diáktársak.) Tucatnyi Gyulaffi Lestámál később érkezett magyar diák viszont vele egy időben (is) koptatta a padokat, ôk név szerint: Bánffy János, Bornemissza István, Bornemissza János, Földváry Miklós, Gernyeszeghi Adám, Horváth Gáspár, Horváth János, Nyáry Pál, Papp Gáspár, Patochy György, Sembery Pál, Serédy Péter, Sibrik Gáspár, Somogyi Farkas, Szendi János, Tardy János, Török Mátyás és Vály Boldizsár. ${ }^{23}$ Közülük Gyulaffi ma ismert följegyzéseiben csak kettőnek a neve fordul elő: Bornemiss a Jánosé és Nyáry Pálé. Egyelőre azonban úgy tűnik, hogy a Gyulaffi által 1594-ben történt elfogatása és kivégzése kapcsán említett ${ }^{24}$ Bornemissza János, Eger egyik nevezetes védőjének, Gergely deáknak kisebbik fia ${ }^{25}$ csak névrokona annak, aki 1572. november 23-án beiratkozott az alsó-ausztriai tartományi iskolába. Az viszont aligha lehet kétséges, hogy a Gyulaffi írásaiban szereplő ${ }^{26}$ Nyáry Pál (†1607. december) egri, majd váradi főkapitány, Bocskay udvari kapitánya, testőrparancsnoka és főudvarmestere ${ }^{27}$ azonos azzal a bécsi diáktárssal, aki 1572. február 22-én lett az iskola tanulója. Megjegyzendő, hogy fönnmaradt jegyzeteiben Gyulaffi sem velük, sem másokkal kapcsolatban nem említi diákéveit.

Megemlékezik viszont róluk, helyesebben csak az egyik esztendőrôl Szamosközyy István (†1612. március 12.) történetíró, levéltáros, aki Gyulaffi szüleinek csaknem összes életrajzi adatát és szinte mindent, ami az ô gyermekkoráról ma ismert - föltehetôen Gyulaffi elmondása alapján - latinul ráírt Gyulaffi egyik beszédének félig üresen maradt hátlapjára. Szamosközy jegyzetének Gyulaffi iskoláztatására vonatkozó része:

„De Eustachio Giǔlaffi

Fuit in schola caesarea Viennae 1573 
BibOr MÁTÉ JÁNOS

$[\ldots]^{\prime 28}$

Azaz:

'Gyulaffi Lestárról

1573-ban a császári iskolában volt Bécsben.'

Feltűnő, hogy az idézett szöveg éppen a diákoskodásról szóló adattal kezdődik. Szamosközy közlése megfelel a valóságnak, csak az érthetetlen, hogy miért éppen ez az évszám szerepel, amikor Gyulaff - legalább részben - négy esztendőt (három tanévet) töltött a császárvárosban. Ennek okát eddig nem sikerült kideríteni, de az is okozhatja, hogy a teljes szövegben szereplő adatok egy része a rögzítéskor már viszonylag régi volt. Emellett szerepet játszhat benne az is - amiből szintén következhetnek hibák -, hogy föltehetően sqóbeli közlés alapján készült. Valószínűtlen ugyanis, hogy egy ilyen tartalmú, Gyulaffi által neki átadott följegyzést Szamosközy csak lemásolt volna, miközben tucatszám őrzött meg Gyulaffitól kapott más iratokat. Ez utóbbiak között volt Gyulaffi 1594. december 15-én Krakkóban, III. (Wasa) Zsigmond lengyel király előtt elmondott szónoklatának autográf javításokat is tartalmazó, saját kezű kézirata, ${ }^{29}$ amelynek félig üres utolsó lapjára írta le Szamosközy az idézett szöveget. Ebből következik jegyzetének terminus post quemje: biztosan Gyulaffinak a követségből való hazatérése, azaz 1595 áprilisának közepe ${ }^{30}$ után készült.

Szerencsére viszonylag sok, az alsó-ausztriai tartományi iskolával kapcsolatos irat maradt fönn, és jelentős részük a Gyulaffi által ott töltött időszakra vonatkozik, köztük az 1573. évi tanterv és egy ugyanebben az esztendőben lezajlott vizsgálat biztosainak jelentése is. Mindezekből viszonylag pontosan rekonstruálható, hogy hogyan teltek a tizenöt-tizennyolc éves Gyulaffi napjai.

Az intézmény rektora vagy másként praeceptora az alapításkor a németalföldi származású Hubertus Luetanus (Novimagnus) lett, aki a bécsi egyetemen 1556-tól 1594-ig dialektikaprofesszor, emellett többször dékán, illetve rektor is volt. A családjával együtt a tartományi iskola épületében lakó rektor irányította az oktatást, amelyben rajta kívül néhány - lehetőleg magisteri, de legalább baccalaureatusi fokozattal rendelkező - segédtanító is részt vett. Utóbbiak együtt étkeztek és aludtak az összesen mintegy három tucat (1573-ban pontosan harminchat) diákkal. Mindkét hálóteremben tizennyolc ágy állt, ezekhez lepedő és takaró is tartozott. Étkezéskor a diákok három asztalt ülhettek körül. A naponta kétszer fölszolgált négyfogásos - az idősebbek számára egy-egy pohár borral teljessé tett - étkezésről a gondnok (oeconomus), az esetleg megbetegedő tanulók ápolásáról és a mosásról a felesége, illetve a szolgája gondoskodott. Ök felügyelték a kémények tisztaságát és kezelték a kapukulcsot is. A bécsi domonkos kolostor melletti épületben működő iskola nyáron hajnali 5-től este 8-ig, télen reggel 6-tól este 7-ig tartott nyitva. A hálótermek és a tanulószobák két-három naponkénti takarítását a két - szintén a diákokkal együtt alvó - szolga végezte. Hetente/nyolc naponta volt hajmosás és fehérneműváltás, kéthetenként fürdőlátogatás. A bentlakó diákoknak két részletben 
évi húsz forintot kellett fizetniük az ételért-italért és a szállásért (ágynemúvel együtt). A helyiek, tehát az intézménybe Bécsből járók (externisták) negyedévente 12 schillinget voltak kötelesek fizetni. Természetesen az oktatás, az ellátás és a szállás költségeit ezek a bevételek csak kis részben fedezték, a tartományi iskola elsősorban az alapításkor erre a célra rendelt évi ezer forint vámjövedelemből múködött, amelyet természetbeni adományok - például bor, liszt, só és fa - egészítettek ki. Emellett előfordult, hogy (elsősorban élelmiszerekkel) a tanulók hozzátartozói is támogatták az intézményt. ${ }^{31}$

A diákokat négy, a manapság szokásoshoz képest fordítva számozott osztályba sorolták. Természetesen minden nap imádkozással kezdődött: a latin nyelvű Pater nostert, Ave Mariát és Veni Sancte Spiritust egy a török elleni oltalomért németül elmondott könyörgés követte. Az 1573-ból fönnmaradt tanterv ${ }^{32}$ szerint ezt követően a negyedik (legalsó) osztályosok reggel és délelőtt két-két órát írással és olvasással, illetve a latin főnév- és igeragozás Donatus ${ }^{33}$ grammatikája alapján történő elsajátításával töltöttek. ${ }^{34}$ Föltételezhető, hogy - talán korábbi tanulmányainak eredményeként - Gyulaffi ezt az „alapozó” osztályt kihagyta, ugyanis 1573-ban a végzősök között szerepel, ${ }^{35}$ és a következő naptári évben csakugyan be is fejezte tanulmányait. Minthogy 1571 ősze és 1574 ősze között éppen három esztendőt töltött az iskolában, ezalatt négy tanévet nem végezhetett el másként, csak úgy, ha az egyiket, természetszerúleg az elsőt, kihagyta. (A későbbiek tananyaga annyira sűrű, hogy akár átugrásuk, akár összevont elvégzésük valószínútlennek tűnik.)

A harmadikosok - tehát a mai számítás szerinti másodikosok - reggel 6-tól 7-ig Melanchton Grammaticäjával, 7-től 8-ig Erasmusnak A gyermeki erkölcsök illendöségéröß ${ }^{6}$ írott múvével foglalkoztak. Ezután egészen délig a bibliai Salamon királynak tulajdonított mondások ${ }^{37}$ alapján végeztek nyelvi gyakorlatokat. Déltől egyig számtan, illetve latin és német írásgyakorlat, 1-től 2-ig Cicero válogatott levelei, ${ }^{38}$ 2-től 3-ig Erasmus Bes₹élgetéseinek kivonata, ${ }^{39}$ illetve Cato Distichonja (helyesebben a neve alatt fönnmaradt aforizmagyüjtemény) következett. Ezt követően a tanultakat vitatták meg. ${ }^{40}$

A másodikosok - azaz a mostani számítás szerinti harmadikosok - reggel 6-tól 7-ig Melanchton Grammaticájával, illetve a lutheri és a kálvini irányzat között közvetíteni igyekvő Johann Sturm (1507-1589) nevével fémjelzett Schola Argentoratensis kisebbik görög grammatikájával, 7-től 8-ig Aiszóposz. meséivel foglalkoztak. Ezután egészen délig Melanchton Syntaxisa következett, amelyet Terentius komédiáival kapcsoltak össze. (Ehhez az órához csatlakoztak a kevésbé jól teljesítő végzősök is.) Déltől egyig zene, illetve számtan (arithmetica), 1-től 2-ig Cicero válogatott leveleinek Johann Sturm-féle gyüjteménye, ${ }^{41}$ 2-től 3-ig ismétlés következett. Ezt követően megvitatták és számonkérték a tanultakat. ${ }^{42}$

Az elsôsök - vagyis a végzősök - 6-tól 7-ig Cicero válogatott leveleivel, 7-tôl 8-ig az általa $A$ kötelességekerô ${ }^{33}$ írott művel foglalkoztak. A délelőtt hátralévő részében az osztály kettévált. A kevésbé jól haladók beültek a másodikosok közé, és ismételten megpróbálták elsajátítani a Melanchton Syntaxisából, illetve a Terentius-komédiákból megtanulhatókat. Ezalatt a végzősök legjobbjai, közöttük talán Gyulaffi is, átsétáltak az iskolájuktól nem messze álló egyetemre, és meghallgatták rektoruk ottani dialektika előadását. Déltől 
egyig - a másodikosokhoz hasonlóan - nekik is zene, illetve számtan következett. Ezután 1-től 2-ig Vergilius Georgicájának magyarázatával, illetve prozódiával foglalkoztak, 2-től 3-ig a Johann Sturm-féle „strassburgi iskola” görög grammatikája és Hésziódosz. művei következtek. A délután hátra lévő részét vitára és a tanultak átismétlésére szánták. ${ }^{44}$

Mindezek mellett hétfőnként Cicero leveleit fordították németre, péntekenként pedig német stílusgyakorlatokat ültettek át latinra. A jól haladók verseket is írtak. (Ma ismert három - egy 1581-ben, ${ }^{45}$ egy 1587-ben ${ }^{46}$ és egy 1586 után ${ }^{47}$ írott - költeménye alapján feltételezhető, hogy így tett Gyulaffi is.) A teljes szombatot a héten tanultak átismétlésére szánták, ezen a napon a diákoknak csak latinul volt szabad beszélniük. Ünnepek (köztük az összes vasárnap) előtt az ifjabbak latinul, az idősebbek pedig görögül olvasták az Evangéliumot. (Az adott részt később föl kellett mondaniuk.) A már említett, 1573-as bizottsági jelentés emellett javasolja, hogy a segédtanítók még többet beszéljenek latinul a diákokkal. A vizsgálóbiztosok ezen felül kívánatosnak tartották Sallustius és Iulius Caesar múveinek olvastatását, illetve szónoklatok és színdarabok (komédiák) tanulását is. ${ }^{48}$ Egyelőre nem tisztázott, hogy ezek bármelyikére sor került-e abban az egy évben, amelyet Gyulaffi még az iskolában töltött.

Gyulaffiról az az Erdélybe érkezése előtti, ma ismert utolsó adat, hogy 1574. szeptember 18-án befejezte tanulmányait az alsó-ausztriai tartományi iskolában. ${ }^{49}$ Konkrétumok híján csak feltételezni lehet, hogy mi történt vele a következő ötödfél évben. Kézenfekvő lenne, hogy valamilyen egyetemen folytatta ismereteinek bővítését, csakhogy ennek sem Gyulaffi fönnmaradt saját följegyzéseiben, sem kortársainak róla tudósító írásaiban, sem pedig a korabeli felsőoktatási intézmények eddig hozzáférhetővé tett diáknévsoraiban nincsen nyoma. Az ilyen jellegű munkák közül Gyulaffit egyedül az erdélyiek kora újkori egyetemjárását bemutató kötet regisztrálja, ${ }^{50}$ ebben azonban - Tonk Sándor Bevezetése szerint - szerepeltetik ,azokat az erdélyi értelmiségieket [is], akik bár megfordultak idegen országokban, egyetemi tanulmányokat nem folytattak, de idehaza rendkívüli intellektuális képességeikről tettek bizonyságot." ${ }^{51}$ A gyűjtemény összeállítói Gyulaffit minden bizonnyal ez utóbbi kategóriába sorolták. (Más kérdés, hogy Gyulaffi csak tanulmányai befejezése után került Erdélybe, tehát azokat nem erdélyiként végezte.) A fentieket figyelembe véve, és életkörülményeit végiggondolva csak arra lehet következtetni, hogy az előbbi adathiány oka az, hogy Gyulaffi Lestár nem járt egyetemre. Ha ez így volt, annak elsősorban anyagi okai lehettek: sem testvéreinek, sem özvegy édesanyjának nem volt elegendő pénze ahhoz, hogy további tanulmányokat finanszírozzon. Aki ezt megtehette volna, Erdélyben nemcsak tanácsúrrá és generálissá, hanem igen gazdaggá is lett nagybátyja, az támogatását szemmel láthatóan csak kapcsolati tőkéje időnkénti fölhasználására korlátozta. Természetesen ez is elismerésre méltó, a családi ellentéteket figyelembe véve különösen, és Gyulaffi Lestár hálás is volt érte, de mit sem változtat azon, hogy ô már az alsó-ausztriai tartományi iskolát is csak nagy anyagi nehézségek árán végezhette el. Erre utal, hogy 1573-1574-re már nagyon elmaradt a tandíjfizetéssel, és még egy évtizeddel később, 1585. július 12-én is adós volt vele. ${ }^{52}$ Hátralékát korábban 
- Pápán szolgáló - bátyja zsoldjából akarták levonni, ${ }^{53}$ azonban Gyulaffi Mihály 1573. február 6-án Szentgyörgyváron törökökkel harcolva súlyosan megsebesült, fogságba esett, és másnap Szigetváron meghalt, ${ }^{54}$ az adósság pedig tovább halmozódott. Arról mindeddig nem sikerült adatot találni, hogy amikor bő másfél évtizeddel később, 1590ben Gyulaffi Lestár újra Bécsben járt, rendezte-e tartozását. ${ }^{55}$

Mindemellett az Erdélyben főúrrá lett pártfogó-nagybátyja, Gyulaffi László alighanem elégedett volt Gyulaffi Lestár bécsi tanulmányainak eredményével, hiszen néhány évvel később saját mostohafiát, a később - elsősorban Bojti Veres Gáspár és Kemény János, illetve Móricz. Zsigmond írói munkásságának eredményeként - híres-hírhedtté vált, ${ }^{56}$ Gyulaffi Lestár által is említett ${ }^{57}$ Imreffy Jánost is az alsó-ausztriai tartományi iskolába járatta. Neki öt és fél évre (1578. április 28.-1583. október 22.) volt szüksége a négy osztály elvégzéséhez. ${ }^{58}$

Összességében az alsó-ausztriai tartományi iskola - mai fogalmak szerint gimnázium - elvégzése megalapozta Gyulaffi Lestár humanista műveltségét. Föltételezhető, hogy ha módjában állt volna egyetemre járni, nem lettek volna tanulmányi problémái, és nyilvánvaló, hogy így, felsőoktatási képzettség nélkül is biztos alapja volt az önmúveléshez.

Itt említendő, hogy Szamoskö̈yy egy helyütt - Borzsák István fordítását idézve - Jósika István „hajdani iskolatársá”-nak nevezi Gyulaffit. ${ }^{59}$ (Az eredetiben „eruditionis communicata habebat studia” áll. ${ }^{60}$ ) Egyelőre nem sikerült kideríteni, hogy ennek mi a valóságalapja. Mert bár 1585-től ismeretlen ideig - lehetséges, hogy akár csaknem egy évtizeden át - Jósikea is a nagyobb kancellária titkára ${ }^{61}$ (tehát Gyulaffi munkatársa), 1594-től haláláig pedig kancellár ${ }^{62}$ (tehát Gyulaffi főnöke) volt, ez mégsem nevezhető korábbi közös tanulásnak. Annak viszont nincs nyoma, hogy az 1598-ban kivégzett Jósika az alsó-ausztriai tartományi iskolába járt volna. Bár nem valószínű, természetesen lehetséges, hogy egy másik, egyelőre ismeretlen helyen voltak iskolatársak. Ez ügyben elsôsorban a lengyelországi Pułtuskban működő jezsuita kollégium jöhet számításba, ahol 1578 és 1582 között Báthory András tanult. ${ }^{63}$ A későbbi kardinális-fejedelem udvartartásának az ifjú Jósika biztosan tagja volt, ${ }^{64}$ azonban az, hogy Gyulaffi is ehhez a körhöz tartozott-e, nagyon kétséges. Egyelőre semmilyen nyoma nincs annak, hogy Gyulaffi Bécsen kívül másutt is diákoskodott volna, és arról sem ismert adat, hogy egyáltalán járt-e Pułtuskban. A kérdés eldöntése tehát további kutatásokat igényel.

A bécsi domonkos templom és mellette a kolostor, valamint a szomszédos épület ma is áll a Dominikanerbastei, a Predigergasse, a Postgasse és a Wollzeile által határolt területen, azonban előbbieket a XVII. században teljesen átépítették, az utóbbi telkén - az egykori alsó-ausztriai tartományi iskola helyén - pedig egy jóval újabb ház található. Így már alig emlékeztet valami arra az épületre, amelyben 1571 és 1574 között Gyulaffi Lestár tanult. 
BibOR MÁTÉ JÁNOS

\section{Jegyzetek és irodalom}

1. Ezúton is hálásan köszönöm Oborni Teréz, S. Sárdi Margit és Szilágyi Emöke Rita észrevételeit, segítségét és tanácsait.

2. BIBOR Máté János: Gyulaffy [sic!] László és Gyulaffi Mihály. Két végvári vitéz Gyulaffi Lestár feljegyzéseiben. = Irodalomismeret, 13. évf. 1/2. sz. 2002. 180-183. p.; Uő.: Gyulaffi Lestár. In: Kőszeghy Péter (főszerk.) - Tamás Zsuzsanna (szerk.): Magyar művelődéstörténeti lexikon. Középkor és kora újkor. III. falkonéta-halászat. Budapest, Balassi Kiadó, 2005. 428. p.; Uő.: Gyulaffi Lestár lengyelországi követjárásai. = Az Egyetemi Könyvtár Évkönyvei, 12. sz. 2005. 121-144. p.; Uő.: Gyulaffi Lestár Erdélyben. In: Balázs Mihály Gábor Csilla (szerk.): Emlékezet és devóció a régi magyar irodalomban. Kolozsvár, Bolyai Társaság - Egyetemi Múhely Kiadó, 2007. (Egyetemi Füzetek, 3.) 495-507. p.; Uő.: Egy értelmiségi a[z Erdélyi] Fejedelemség szolgálatában. = Hepehupa, 10. évf. 3. sz. 2011. 21-33. p. [2., jav. kiad.: Tövisháti Füzetek 2016, 10-20. p.]; Uo.: „Meg-írta a’ maga ideje-béli Erdélyi dolgokat". Gyulaffi Lestár följegyzéseinek, levelezésének és naplójának ma ismert töredékei. In: Jankovics József [et al.] (szerk.): Stephanus noster. Tanulmányok Bartók István 60. születésnapjára. Budapest, Reciti, 2015. 127-140. p.; Uő.: Gyulaffi Lestár született..., de mikor is? Avagy az információkészítés buktatói. In: Kiszl Péter - Németh Katalin (szerk.): Információközvetítés és közösségépítés - multifunkciós könyvtári hálózatok. Budapest, ELTE BTK Könyvtár- és Információtudományi Intézet, 2020. 31-39. p. Forrás: https:// doi.org/10.21862/infkoz.31

3. SZABÓ Károly (bev., kiad.): Gyulafi [sic!] Lestár Följegyzései. In: Magyar történelmi emlékek és naplók a XVI-XVIII. századokból. Budapest, M. Tud. Akadémia könyvkiadó-hivatala, 1881. (Monumenta Hungariae Historica - Scriptores, 31.) 1-124. p.; Szilágyi Sándor (bev., kiad.): Gyulaffi Lestár Történelmi maradványai. In: Magyar történelmi emlékek és naplók a XVI-XVIII. századokból 2. Budapest, Magyar Tud. Akadémia könyvkiadó-hivatala, 1894. (Monumenta Hungariae Historica - Scriptores, 33.) 1-80. p.

4. PÁLFFY Géza: A veszprémi végvár fő- és vicekapitányainak életrajzi adattára (16-17. század). In: Tóth G. Péter (szerk.): Veszprém a török korban. Felolvasóülés Veszprém török kori emlékeiről. Veszprém, Laczkó Dezső Múzeum - Veszprém Megyei Múzeumi Igazgatóság, 1998. (Veszprémi Múzeumi Konferenciák, 9.), 91-188. p., hivatkozott rész: 111-112, 142-144. p.

5. BIBOR Máté János: Egy életút Csobánctól Szilágycsehig. = Hepehupa, 8. évf. 3. sz. 2009. 48-54. p. [2., jav. kiad.: Tövisháti Füzetek 2016, 2-9. p.]

6. Vö. PETTKÓ Béla (kiad): Choronné levele fia kiszabadítása ügyében. 1573. febr. 13. [vagy 16?] = Történelmi Tár, 1887. 803-804. p.

7. Vö. KOMÁROMY András (kiad.): Magyar levelek a XVI. századból. Befejező közlemény. = Történelmi Tár, 1911. 537-564. p., hivatkozott rész: 547-554. p., az egyik levél betűhű kiadása és fényképközlése: Bak Borbála: A XVI-XVIII. századi magyar nyelvű források kiadásának kérdései. $=$ Fons, 7. évf. 1. sz. 2000. 91-137. p., hivatkozott rész: 133-137. p.

8. BORSA Gedeon [et al.]: Régi magyarországi nyomtatványok 1473-1600. Budapest, Akadémiai Kiadó, 1971. 281-282. p., no. 259.

9. GYULAFFI Történelmi maradványai, i. m. 52. p., kézirat: Eötvös Loránd Tudományegyetem Egyetemi Könyvtár (ELTE EK), Litterae et epistolae originales (LEO) 272b, fol. 87 


\section{GYULAFFI LESTÁR DIÁKÉVEI}

10. IVÁNYI Béla: Könyvek, könyvtárak, könyvnyomdák Magyarországon. (Második közlemény.) = Magyar Könyvszemle, Új folyam 36. évf. 1929. 193-208. p., hivatkozott rész: 208. p.

11. GYULAFI Följegyzései, i. m. 91-93. p.

12. GYULAFFI Történelmi maradványai, i. m. 51. p., kézirat: ELTE EK, LEO 272b, fol. 84v

13. HORN Ildikó: A főnemesi iskoláztatás változásai az Erdélyi Fejedelemségben. = Barokk. Történelem - Irodalom - Művészet, 2010/Különszám, 109-124. p., hivatkozott rész: 117. p.

14. GECSÉNYI Lajos: Magyar diákok a bécsi tartományi iskolában a 16. század második felében. = Történelmi Szemle, 34. évf. 1/2. sz. 1992. 95-106. p., hivatkozott rész: 99. p.

15. [SZILÁGYI Sándor] (kiad.): Maximilián menedéklevele Gyulafy [sic!] László számára. = Történelmi Tár, 1887. 805-806. p.

16. PÁLFFY Géza szíves közlése, amelyet ezúton is köszönök.

17. PÁLFFY Géza: Koronázási lakomák a 15-17. századi Magyarországon. = Századok, 138. évf. 5. sz. 2004. 1005-1101. p., hivatkozott rész: 1069. p.

18. GECSÉNYI Lajos: i. m. 96. p.

19. BARTÓK István: „Nem egyéb, hanem magyar poézis”. Sylvester János nyelv- és irodalomszemlélete európai és magyar összefüggésekben. Budapest, Universitas Kiadó, 2007. (Klasszikusok) 32-51. p., különösen: 37-38. p.

20. FINÁCZY Ernő: A renaissancekori nevelés története. Vezérfonal egyetemi előadásokhoz. Budapest, Hornyánszky Viktor, 1919. 224-234. p.

21. GECSÉNYI Lajos: i. m. 98., 106. p.

22. PÁLFFY Géza: i. m. 1998. 143. p.

23. GECSÉNYI Lajos: i. m. 99-100. p.

24. GYULAFFI Történelmi maradványai, i. m. 16-17. p., kézirat: ELTE EK, LEO 272b, fol. $73^{\mathrm{v}}, 75^{\mathrm{r}}$

25. SUGÁR István: Bornemissza Gergely deák élete. Eger, Dobó István Vármúzeum, 1984. (Studia Agriensia, 4.) 12-13, 120-124. p.

26. Például: GYULAFFI Történelmi maradványai, i. m. 50. p., kézirat: ELTE EK, LEO 272b, fol. $84^{\mathrm{r}}$

27. BENDA Kálmán: Bocskai István székhely nélküli fejedelmi udvara. In: R. Várkonyi Ágnes (szerk.): Magyar reneszánsz udvari kultúra. Budapest, Gondolat Könyvkiadó, 1987. 158-165, 361. p., hivatkozott rész: 161. p.; PAPP Klára: Bocskai kassai fejedelmi udvara. In: Ifj. Barta János - P. K. (szerk.): „Nincsen nekönk több hazánk ennél...” Tanulmányok a Bocskai-felkelés történetéhez. Budapest, Lucidus Kiadó, 2004. (Kisebbségkutatás Könyvek) 121-144. p., hivatkozott rész: 135. p.

28. SZILÁGYI Sándor (bev., kiad.): SZAMOSKÖZY István Történeti maradványai 1542_ 1608. IV. Vegyes följegyzések. Budapest, M. Tud. Akadémia könyvkiadó-hivatala, 1880. (Monumenta Hungariae Historica - Scriptores, 30.) 63. p., kézirat: ELTE EK, LEO 1358, fol. $69^{\mathrm{v}}$

29. GYULAFI Följegyzései, i. m. 95-98. p., kézirat: ELTE EK, LEO 1358, fol. 68-69

30. NUSSBÄCHER, Gernot: Adatok Gyulafi Lestár utazásaihoz. Bev. K[eserú] B[álint]. Szeged, [JATE BTK], 1972. (Irodalomtörténeti Dolgozatok, 67) = klny.: Acta Historiae Litterarum Hungaricarum, 10/11. sz. 1971. 37-42. p.; GYULAFFI Történelmi maradványai, i. m. 26. p., kézirat: ELTE EK, LEO 272b, fol. 44

31. GECSÉNYI Lajos: i. m. 96-97., 100., 105. p. 
BibOr MÁTÉ JÁNOS

32. Catalogus lectionum et omnium exercitationum. Hanc Caesarae Maiestatis scholam studiorum causa ingressi non tantum in bonis litteris et artibus, sed etiam virtutibus probatisque moribus magna praeceptorum cura et diligentia instituantur

33. Aelius Donatus (IV. század) római grammatikus két részre (Ars minor és Ars maior) osztott kézikönyvét (Ars Donati) Európában több mint ezer éven át használták latintankönyvként. Vö. ALBRECHT, Michael von: A római irodalom története II. Ford. Tar Ibolya. Budapest, Balassi Kiadó, 2004. 1187. p.

34. GECSÉNYI Lajos: i. m. 97. p.

35. GECSÉNYI Lajos: i. m. 99. p.

36. De civilitate morum puerilium

37. Példabeszédek könyve 10,1-22,16 és 25,1-29,27

38. Epistolae selectiores

39. Epitome colloquiorum

40. GECSÉNYI Lajos: i. m. 97. p.

41. KECSKEMÉTI Gábor: „A böcsületre kihaladott ékes és mesterséges szollás, írás”. A magyarországi retorikai hagyomány a 16-17. század fordulóján. Budapest, Universitas Kiadó, 2007. (Irodalomtudomány és Kritika. Tanulmányok) 109-110., 115-120. p.

42. GECSÉNYI Lajos: i. m. 98. p.

43. De officiis

44. GECSÉNYI Lajos: i. m. 98. p.

45. GYULAFI Följegyzései, i. m. 49. p., műfordítása: TÓTH István: A gyulafehérvári humanista költészet antológiája. „Költők virágoskertje”. Budapest, Accordia Kiadó, 2001. (Hagyományőrző Könyvek, 1.) 108. p.

46. GYULAFI Följegyzései, i. m. 22-23. p., műfordítása: TÓTH: A gyulafehérvári humanista költészet..., i. m. 108. p.

47. GYULAFI Följegyzései, i. m. 19. p., kézirat: ELTE EK, LEO 188, fol. $15^{\mathrm{r}}$

48. GECSÉNYI Lajos: i. m. 98., 105-106. p.

49. GECSÉNYI Lajos: i. m. 99. p.

50. SZABÓ Miklós - TONK Sándor: Erdélyiek egyetemjárása a korai újkorban. 1521-1700. Szeged, József Attila Tudományegyetem, 1992. (Fontes rerum scholasticarum, 4.) 50. p., no. 478

51. TONK Sándor: Bevezetés. In: Szabó - Tonk: Erdélyiek egyetemjárása..., i. m. vii-xi. p., hivatkozott rész: ix-x. p.

52. Ernő főherceg a hátralékos térítési dijak behajtása ügyében 1585. július 12-én a Magyar Kamarához fordult. A leirat szerint Gyulaffi 1573-1574-ben nem fizetett, a névsorban Gyulai Eustachiusként szerepel. Idézi: [FRAKNÓI =] FRANKL Vilmos: A hazai és külföldi iskolázás a XVI. században. Budapest, Eggenberger F. magyar akadem. könyvárusnál, 1873. 208. p.

53. GECSÉNYI Lajos: i. m. 102. p.

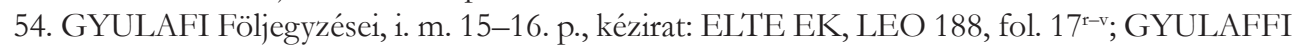
Történelmi maradványai, i. m. 52. p., kézirat: ELTE EK, LEO 272b, fol. 87

55. Erről a látogatásról szól majd, és Gyulaffinak az 1590-es bécsi földrengésről írott beszámolóját ismerteti jelen tanulmány készülőfélben lévő folytatása.

56. NAGY László: A „feleségkiáruló Kurafi János”. In: Uő.: Botránykövek régvolt históriánkban. Budapest, Akadémiai Kiadó, 1997. 179-213. p. 
57. Például: GYULAFI Följegyzései, i. m. 45-47. p., kézirat: ELTE EK, LEO 1523/4, fol. $1^{\text {r-v }}$ 58. GECSÉNYI Lajos: i. m. 100. p.

59. SZAMOSKÖZY István: Erdély története (1598-1599, 1603). Budapest, Magyar Helikon, 1977 (Bibliotheca Hungarica), 69. p.

60. SZILÁGYI Sándor (kiad.): SZAMOSKÖZY István Történeti maradványai 1566-1603. II. 1598-1599. Budapest, A Magyar Tudományos Akadémia könyvkiadó hivatala, 1876. (Monumenta Hungariae Historica - Scriptores, 28.) 25. p.

61. TRÓCSÁNYI Zsolt: Erdély központi kormányzata 1540-1690. Budapest, Akadémiai Kiadó, 1980. (A Magyar Országos Levéltár Kiadványai. Hatóság- és Hivataltörténet, III/6) 185. p.

62. TRÓCSÁNYI Zsolt: i. m. 181. p.

63. HORN Ildikó: Báthory András. Budapest, Új Mandátum Könyvkiadó, 2002. (Post Scriptum Életrajzi Monográfiák, 3.) 22-43. p.

64. HORN Ildikó: i. m. 30. p.

Bibor Máté János - könyvtáros, irodalomtörténész 2003 és 2014 között az ELTE Egyetemi Könyvtár régikönyves munkatársa, 2004-tôl tart órákat az ELTE BTK-n, ahol 2014-től a KITI fóállású tanársegéde. Kutatási területei közép- és koraújkori könyv-, könyvtár- és nyomdászattörténet, a zirci apátsági könyvtár története és ősnyomtatványai; Gyulaffi Lestár erdélyi emlékíró élete és fennmaradt írásai. ORCID: 0000-0002-1062-3813 